\title{
GMR
}

\section{Analysis of p53 gene polymorphism (codon 72) in symptomatic patients with atherosclerosis}

\author{
M.H. Lagares ${ }^{1,2}$, K.S.F. Silva ${ }^{1}$, A.M. Barbosa ${ }^{1,2}$, D.A. Rodrigues ${ }^{1,2}$, \\ I.R. Costa ${ }^{1,2}$, J.V.M. Martins ${ }^{1,2}$, M.P. Morais ${ }^{1,2}$, F.L. Campedelli ${ }^{1,2}$ and \\ K.K.V.O. Moura ${ }^{1,2}$ \\ ${ }^{1}$ Núcleo de Pesquisa Replicon, Pontifícia Universidade Católica de Goiás, \\ Goiânia, GO, Brasil \\ ${ }^{2}$ Departamento de Biomedicina, Pontifícia Universidade Católica de Goiás, \\ Goiânia, GO, Brasil \\ Corresponding author: K.S.F. Silva \\ E-mail: smallbinho@hotmail.com \\ Genet. Mol. Res. 16 (3): gmr16039721 \\ Received May 12, 2017 \\ Accepted June 21, 2017 \\ Published August 17, 2017 \\ DOI http://dx.doi.org/10.4238/gmr16039721 \\ Copyright $(92017$ The Authors. This is an open-access article distributed under the terms of \\ the Creative Commons Attribution ShareAlike (CC BY-SA) 4.0 License.
}

\begin{abstract}
Atherosclerosis is a multifactorial pathological disease that alters the morphology and function of arterial walls. The atheroma growth leads to vessel hardening and lumen narrowing, limiting the blood flow. The atheroma plaque can eventually break, expose highly thrombogenic material and lead to platelet activation and subsequent formation of a thrombus that may block blood flow in loco, or even leading to obstruction of other vessels with a smaller diameter. This process is one of the main determinants of the clinical manifestations of atherosclerosis, such as coronary artery disease, ischemic stroke, and peripheral arterial disease. Although the inflammatory theory about atherosclerosis is the most renowned one, observations point to common biological characteristics between cancer and atherosclerosis suggesting a possible association between p53 and atherosclerotic diseases. We collected peripheral blood samples from 200 individuals with clinical manifestations of atherosclerotic disease and 100 individuals without manisfestation of
\end{abstract}

Genetics and Molecular Research 16 (3): gmr16039721 
the disease to form the control group. DNA was subjected to molecular analysis (PCR) to identify the polymorphism of the p53 gene. We have not found any relationship between the polymorphism of the p53 gene and atherosclerosis in the population studied $(\mathrm{P}=0.36)$. There was no relationship between atherosclerosis, polymorphism of p53 and the variables accounted: smoking habit $(\mathrm{P}=0.72,0.51$ and 0.62 for smokers, non-smokers and former smokers respectively), alcohol consumption ( $\mathrm{P}$ $=0.17$ for individuals with drinking habits and 0.38 for those who do not consume alcohol beverage), systemic arterial hypertension $(\mathrm{P}=0.60)$, diabetes mellitus $(\mathrm{P}=0.34)$, and dyslipidemia $(\mathrm{P}=0.89)$. Our population has a high rate of miscegenation and heterozygotes, and according to studies the arginine variant is more related to plaque formation because it induces apoptosis more frequently when compared to the proline variant. According to our results, there is no association between the polymorphism of the p53 gene, atherosclerosis and its risk factors in the population studied.

Key words: Atherosclerosis; Polymorphism; p53

\section{INTRODUCTION}

Atherosclerotic disease (AD) and cardiovascular diseases (CVD) are part of the group of chronic noncommunicable diseases that make up the plurimetabolic syndrome (obesity, hypertension, diabetes mellitus and dyslipidemia). Generally, the clinical manifestations of these diseases are myocardial infarction, stroke and peripheral vascular disease, caused by a process of atherosclerosis that starts from middle age (Söderström et al., 2014).

$\mathrm{AD}$ is responsible for the main cause of disability and mortality in Brazil and worldwide (Mansur and Favarato, 2012; Yang et al., 2014). Heart diseases also represent a major health problem worldwide, accounting for the highest costs in medical care. In Brazil, they account for about $20 \%$ of all deaths in individuals over 30 years of age. AD became an epidemic disorder with increased population survival to infectious diseases; in addition, several societies adopted dietary habits that foster the development of atherosclerosis, such as excessive saturated fats and decreased physical activity practices (Mansur and Favarato, 2012).

Several risk factors, such as dyslipidemia, systemic arterial hypertension, diabetes mellitus, and smoking lead to endothelium aggression. Therefore, to the endothelial dysfunction, the permeability of the intima to plasma lipoproteins increases, favoring their retention into the subendothelial space and AD onset (Hansson, 2005).

In the last two decades, development in the field of vascular biology has clarified that atherosclerotic lesions are in fact a series of highly specific and dynamic cellular and molecular responses, essentially inflammatory in nature. The evidence indicates that the fundamental event for the onset of the lesions is the accumulation of plasma-derived lipoproteins in the arterial intima. It triggers specific cellular reactions, of which endothelial dysfunction and the inflammatory state are the main components associated with the activation of the immune system. There is an interaction between activated endothelial cells, modified low-density lipoproteins (LDLs), macrophages, monocyte derivatives, $\mathrm{T}$ cells, and the vessel wall that leads to inflammation (Casella et al., 2003).

Genetics and Molecular Research 16 (3): gmr16039721 
The migration and proliferation of smooth muscle cells from arterial middle layer to intima is stimulated by mediators of inflammation and stimulate the production of cytokines, growth factors and extracellular matrix, which will form part of the fibrous layer of the atherosclerotic plaque (Hansson, 2005). The formation of the plaque is an irreversible process, related to the destruction of the vascular wall architecture and composed by foam cells, cellular debris (from apoptosis and consequent necrosis), cholesterol, calcium esters, smooth muscle, and extracellular matrix (responsible for the fibrous cap) (Casella et al., 2003).

Genetic factors play a key role on the development and onset of AD. The p53 gene is a classic tumor suppressor gene, known as the guardian of the genome that regulates cell cycle and consequently cellular growth. The gene is located in the locus $17 \mathrm{p} 13.1$, with $20 \mathrm{~kb}$ and composed of 11 exons, highly conserved, presenting structural homology between different species. It encodes the synthesis of a nuclear phosphoprotein of $53 \mathrm{kDa}$ and 393 amino acids, named $\mathrm{p} 53$ protein as a function of its molecular weight. The p53 gene encodes the synthesis of a nuclear phosphoprotein of $53 \mathrm{kDa}$, where the name p53 comes from, and the protein has 393 amino acids. The functionally active (wild-type) form of p53 has a tetrameric molecular structure (Kung and Murphy, 2016).

The $\mathrm{p} 53$ protein is activated when DNA damage occurs by exogenous and endogenous agents, and the consequence of its positive regulation is the induction of pathways leading to cell cycle arrest or apoptosis. The protein slows the progression of the cell cycle when it interacts with the damaged DNA site. Activated p53 makes the p21-waf gene to become activated, and the $\mathrm{p} 21$ protein is then synthesized, interacts with the kinase-dependent cyclin 2 receptor (cdk2), the latter stimulates cell division (Syvänen, 2001). When p21 forms complexes with cdk2, the cell is prevented from advancing to the next stage of cell division by blocking the cells in the G1 phase of the cell cycle, giving time for DNA repair to occur (Levine, 1997). If the damage is irreparable, the p53 protein stimulates apoptosis of the cells, contributing to the protection of the organism against the accumulation of genetic mutations and avoiding the occurrence of genetically unstable cells with a predisposition to malignant transformation. Mutated p53 does not activate p21 production, making cell division uncontrolled (Syvänen, 2001).

The p53 polymorphism occurs by simple substitution of a base at codon 72, which results in structural alteration of the protein (Syvänen, 2001). Mutant p53 proteins, which differ from the wild type in only one amino acid residue, generally lose the ability to bind to DNA. Mutations of p53 are generally found in conserved regions of the protein, about $74 \%$ of these mutations are missense (Pietenpol et al., 1994).

The p53 codon 72 of exon 4 shows a polymorphism characterized by a substitution of guanine $(\mathrm{G})$ by a cytosine $(\mathrm{C})$, which determines the alteration of the amino acid arginine to proline in the protein. This specific amino acid change affects biochemical and functional properties of p53. There are three different genotypes regarding p53 codon 72, arg/arg, arg/ pro, pro/pro (Gloria-Bottini et al., 2012). Studies in cell lines containing the inducible coding version of variants, arginine and proline, have demonstrated that the arginine variant is capable of inducing apoptosis at least five times better than the proline variant (Doosti et al., 2011)

Although the inflammatory theory of $\mathrm{AD}$ is the most prominent, observations point to common biological characteristics between cancer and atherosclerosis (Casella et al., 2003), suggesting a possible association of $\mathrm{p} 53$ with atherosclerotic diseases, but data regarding the latter are controversial (Gloria-Bottini et al., 2012).

In the present study, we analyzed codon p53 72 polymorphism in 300 individuals,

Genetics and Molecular Research 16 (3): gmr16039721 
200 of which with clinical manifestations of AD. We also analyzed the polymorphism, clinical manifestations of $\mathrm{AD}$ and smoking habit, alcohol, systemic arterial hypertension, diabetes, and dyslipidemia.

\section{MATERIAL AND METHODS}

The present study was approved by the National Ethics Commission in Research/ National Information System on Ethics in Research involving Human Beings CEP/PUC Goiás (No. 35321614.3.0000.0037). All patients were older than 38 years of age, all of them signed the informed consent term and agreed to participate in the research.

We collected peripheral blood samples from 300 patients, at the angiogenesis/vascular surgery and cardiology department of Angiogyn clinic, located in the city of Goiânia. Among those patients, 200 had a previous diagnosis of either peripheral and/or central AD, evaluated through clinical history, physical examination and confirmed by angiography. The other 100 patients formed the control group with the absence of $\mathrm{AD}$, diagnosis based on clinical manifestations and non-invasive imaging, as well as the absence of risk factors for the disease, systemic arterial hypertension, diabetes mellitus, and dyslipidemia.

DNA extraction was performed according to Kaswi ${ }^{\circledR}$ (Genomic DNA Purification Kit) instructions. After extraction, the samples were quantified in the NanoVue ${ }^{\mathrm{TM}}$ Plus spectrophotometer (GE, Cambridge, UK) according to the manufacturer instructions, with relevance only to samples whose quantification results about DNA concentration were higher than $5 \mathrm{ng} / \mu \mathrm{L}$. DNA was stored at $-20^{\circ} \mathrm{C}$ until amplification by polymerase chain reaction (PCR) method.

Samples were subjected to PCR amplification to detect the polymorphism of the p53 gene. The final volume of the reaction was $25 \mu \mathrm{L}$. All analyzes were performed in duplicate. The resultant fragments were subjected to $1.5 \%$ agarose gel electrophoresis in 1X EDTA Trisborate solution (TBE) in an electric field of $10 \mathrm{~V} / \mathrm{cm}$. The gels were stained with ethidium bromide $(5 \mu \mathrm{g} / \mathrm{mL})$ and the visual record was made on the BIORAD Photodocumentator (BioRad, Hercules, CA, USA).

In the analysis for p53 gene codon 72 polymorphism, the primer Pro-72 (F-5'GCCAGAGGCTGCTCCCCC-3' and R-5'-CGTGCAAGTCACA GACTT-3') was designed for p53 codon 72 in the proline form and Arg-72 (F-5'-TCCCCCTTGCCGTCCCAA-3' and R-5'-CTGGTGCAGGGGCCACGC-3'), according to the protocol adapted from Lattuada et al. (2004). The results of the p53 gene polymorphism were organized into Excel spreadsheets, composing a database. We performed the statistical analysis based on G-test test to analyze the relationship between polymorphism and atherosclerotic disease. The value of $\mathrm{P}<0.05$ was considered to be statistically significant. The statistical tests were carried out using BioEstat ${ }^{\mathbb{R}}$ 5.0 (Ayres et al., 2007).

\section{RESULTS}

In the investigation of the polymorphism in codon 72 of the p53 gene, we found for the case group 4.5\% (09/200) of homozygotes with the proline variant, 15\% (30/200) of homozygotes with the arginine variant and $80.5 \%(161 / 200)$ were $\arg /$ pro heterozygotes. For the control group we found that 3\% (3/100) were pro/pro, 10\% (10/100) were arg/arg and $87 \%$ (87/100) were arg/pro. The P value was 0.36 (Table 1).

Genetics and Molecular Research 16 (3): gmr16039721 
Table 1. Distribution of the polymorphism of the p53 gene in the case and control groups.

\begin{tabular}{|c|c|c|c|c|c|c|c|c|c|}
\hline & \multicolumn{6}{|c|}{ Genotype } & \multirow{2}{*}{\multicolumn{2}{|c|}{ Total }} & \multirow[t]{3}{*}{$\mathrm{P}^{*}$} \\
\hline & \multicolumn{2}{|c|}{ pro/pro } & \multicolumn{2}{|c|}{ arg/arg } & \multicolumn{2}{|c|}{ arg/pro } & & & \\
\hline & $\mathrm{N}$ & $\%$ & $\mathrm{~N}$ & $\%$ & $\mathrm{~N}$ & $\%$ & $\mathrm{~N}$ & $\%$ & \\
\hline Case & 9 & 4.5 & 30 & 15.0 & 161 & 80.5 & 200 & 100.0 & 0.36 \\
\hline Control & 3 & 3.0 & 10 & 10.0 & 87 & 87.0 & 100 & 100.0 & \\
\hline
\end{tabular}

*G-test.

Regarding the risk factors for systemic arterial hypertension, diabetes mellitus and dyslipidemia, a comparison was made between affected and non-affected patients for the case group. The association of the risk factor hypertension in the case group with the frequency of p53 genotypes, we observed 4.2\% (7/166) of patients with pro/pro, $14.5 \%(24 / 166)$ with arg/ arg and $81.3 \%$ (135/166) with arg/pro. Regarding the patients not affected by hypertension, the frequency was $5.9 \%(2 / 34)$ pro/pro, $20.6 \%(7 / 34) \mathrm{arg} / \mathrm{arg}$ and $73.5 \%(25 / 34) \mathrm{arg} / \mathrm{pro}$ as described in Table $2(\mathrm{P}=0.60)$.

The evaluation of the association of $\mathrm{p} 53$ polymorphism and individuals with diabetes in the case group we found 7.1\% (4/56) pro/pro, 10.7\% (6/56) arg/arg 82.1\% (46/56) arg/ pro. Regarding patients free from diabetes, the frequency was $3.5 \%(5 / 144)$ pro/pro, $16.7 \%$ (24/144) $\mathrm{arg} / \mathrm{arg}$ and $79.9 \%$ (115/144) $\mathrm{arg} / \mathrm{pro}, \mathrm{P}=0.34$ as detailed in Table 2.

For individuals with the risk factor dyslipidemia in the case group, the frequency of genotypes was 5.2\% (5/97) pro/pro, 14.4\% (14/97) arg/arg and 80.4\% (78/97) arg/pro. The genotype frequencies of patients free from dyslipidemia was 3.9\% (4/103) pro/pro, $15.5 \%$ $(16 / 103) \mathrm{arg} / \mathrm{arg}$ and $80.6 \%(83 / 103) \mathrm{arg} / \mathrm{pro}, \mathrm{P}=0.89$ according to Table 2.

\begin{tabular}{|c|c|c|c|c|c|c|c|c|c|}
\hline & \multicolumn{6}{|c|}{ Genotype } & \multirow{2}{*}{\multicolumn{2}{|c|}{ Total }} & \multirow[t]{3}{*}{$\mathrm{P}^{*}$} \\
\hline & \multicolumn{2}{|c|}{ pro/pro } & \multicolumn{2}{|c|}{ arg/arg } & \multicolumn{2}{|c|}{ arg/pro } & & & \\
\hline & $\mathrm{N}$ & $\%$ & $\mathrm{~N}$ & $\%$ & $\mathrm{~N}$ & $\%$ & $\mathrm{~N}$ & $\%$ & \\
\hline Hipertensive & 07 & 4.2 & 24 & 14.5 & 135 & 81.3 & 166 & 100 & 0.60 \\
\hline Normotensive & 02 & 5.9 & 07 & 20.6 & 25 & 73.5 & 34 & 100 & \\
\hline With diabetes & 4 & 7.1 & 6 & 10.7 & 46 & 82.1 & 56 & 100 & 0.34 \\
\hline No diabetes & 5 & 3.5 & 24 & 16.7 & 115 & 79.9 & 144 & 100 & \\
\hline Dyslipidemic & 5 & 5.2 & 14 & 14.4 & 78 & 80.4 & 97 & 100 & 0.89 \\
\hline No dyslipidemia & 4 & 3.9 & 16 & 15.5 & 83 & 80.6 & 103 & 100 & \\
\hline
\end{tabular}

${ }^{*}$ G-test.

We also analyzed the genotypic distribution of patients regarding smoking habits (Table 3 ), in the case group and in the control group. The patients were classified into 3 groups, smokers, non-smokers and ex-smokers according to their statement. We found no association of the 53 polymorphism with $\mathrm{AD}$ and smoking risk factor in any of the groups studied. The $\mathrm{P}$ values were: smokers $\mathrm{P}=0.72$, non-smokers $\mathrm{P}=0.51$ and ex-smokers $\mathrm{P}=0.62$.

We analyzed the $\mathrm{p} 53$ polymorphism about the consumption of alcoholic beverage (Table 4), a greater number of individuals who declared themselves nonconsumers were observed in both the 90.4 and $78.7 \%$ control groups. The P-values for ethylics were $\mathrm{P}=0.17$ and non-ethylene $\mathrm{P}=0.38$. In this study, there was no association between the polymorphism of the p53 gene and atherosclerotic disease and the alcoholism risk factor. The $\mathrm{P}$ values were $\mathrm{P}$ $=0.17$ for the group who declared to consume alcohol beverages and $\mathrm{P}=0.38$ for the ones who

Genetics and Molecular Research 16 (3): gmr16039721 
do not have a drinking habit. In this study, there was no association between the polymorphism of the p53 gene, $\mathrm{AD}$ and the risk factor alcoholism.

\begin{tabular}{|c|c|c|c|c|c|c|c|c|c|}
\hline & \multicolumn{6}{|c|}{ Genotypes } & \multirow{2}{*}{\multicolumn{2}{|c|}{ Total }} & \multirow[t]{3}{*}{$\mathrm{P}^{*}$} \\
\hline & \multicolumn{2}{|c|}{ pro/pro } & \multicolumn{2}{|c|}{ arg/arg } & \multicolumn{2}{|c|}{ arg/pro } & & & \\
\hline & $\mathrm{N}$ & $\%$ & $\mathrm{~N}$ & $\%$ & $\mathrm{~N}$ & $\%$ & $\mathrm{~N}$ & $\%$ & \\
\hline \multicolumn{10}{|l|}{ Smoker } \\
\hline Case & 4 & 5.8 & 9 & 13.0 & 56 & 81.2 & 69 & 100 & 0.72 \\
\hline Control & 1 & 4.0 & 2 & 8.0 & 22 & 88.0 & 25 & 100 & \\
\hline \multicolumn{10}{|c|}{ Non-smoker } \\
\hline Case & 3 & 3.5 & 12 & 14.1 & 70 & 82.4 & 85 & 100 & 0.51 \\
\hline Control & 2 & 3.2 & 5 & 8.1 & 55 & 88.7 & 62 & 100 & \\
\hline \multicolumn{10}{|c|}{ Ex-smoker } \\
\hline Case & 2 & 4.8 & 8 & 19.0 & 32 & 76.2 & 42 & 100 & 0.62 \\
\hline Control & 0 & 0.0 & 2 & 18.2 & 9 & 81.8 & 11 & 100 & \\
\hline
\end{tabular}

${ }^{*} \mathrm{G}$-test.

\begin{tabular}{|c|c|c|c|c|c|c|c|c|c|}
\hline & \multicolumn{6}{|c|}{ Genotypes } & \multirow{2}{*}{\multicolumn{2}{|c|}{ Total }} & \multirow[t]{3}{*}{$\mathrm{P}^{*}$} \\
\hline & \multicolumn{2}{|c|}{ pro/pro } & \multicolumn{2}{|c|}{ arg/arg } & \multicolumn{2}{|c|}{ arg/pro } & & & \\
\hline & $\mathrm{N}$ & $\%$ & $\mathrm{~N}$ & $\%$ & $\mathrm{~N}$ & $\%$ & $\mathrm{~N}$ & $\%$ & \\
\hline \multicolumn{10}{|c|}{ Alcohol consumption } \\
\hline Case & 0 & 0.0 & 4 & 21.1 & 15 & 78.9 & 19 & 100 & \multirow[t]{2}{*}{0.17} \\
\hline Control & 1 & 5.0 & 1 & 5.0 & 18 & 90.0 & 20 & 100 & \\
\hline \multicolumn{10}{|c|}{ Non-consumers } \\
\hline Case & 9 & 5.1 & 25 & 14.0 & 144 & 80.9 & 178 & 100 & \multirow[t]{2}{*}{0.38} \\
\hline Control & 2 & 2.7 & 7 & 9.5 & 65 & 87.8 & 74 & 100 & \\
\hline
\end{tabular}

*G-test.

\section{DISCUSSION}

Atherosclerosis is a pathology of multifactorial origin and is a challenge for molecular genetics, being responsible for the highest morbidity and mortality in Brazil and worldwide (IBGE, 2010; World Health Organization, 2014). As the risks of the disease, the precocious symptoms and their complications, as well as in the absence of the traditional risk factors seem to increase, the study of the genetic susceptibility to AD become more evident (Mohan et al., 1998).

Knowledge of the genetic profile may benefit more susceptible individuals with early of preventive and drug measures with better prognostic and consequent longer survivability and quality of life.

In the present study, the frequency of arg/pro, arg/arg and pro/pro genotypes in $\mathrm{AD}$ patients did not differ significantly from those who did not present the disease. We found no association between the polymorphism of the p53 gene and AD. Our results corroborate a study conducted by Manfredi et al. (2002) with 250 Italian individuals, which also did not find an association between the polymorphism of the p53 gene and AD. Smith et al. (2007) analyzed 383 elderly patients with variants of AD and could not establish any association between this polymorphism and cardiovascular diseases.

Alkhalaf et al. (2007) found no association between codon 72 polymorphism of the p53 gene and CAD or diabetes in Kuwait individuals. D'Agostini et al. (1995) analyzed abdominal aorta fragments collected in the surgery of 32 patients. The results obtained did

Genetics and Molecular Research 16 (3): gmr16039721 
not indicate a relation between the polymorphism of the p53 gene and the pathogenesis of atherosclerotic lesions. Opposedly, Gloria-Bottini et al. (2012) investigated the possible association of polymorphism in the 72 codon of the p53 gene with left ventricular ejection fraction (LVEF) in individuals with and without CAD and concluded that there is a significant relation between this polymorphism and cardiac function in patients with the disease. Wang et al. (2007) evaluated showed and association of the effects of glutathione S-transferase M1, T1, $\mathrm{P} 1$, the p53 genetic polymorphisms and exposure to arsenic on the risk of developing carotid atherosclerosis.

A study in a group of patients aged 66-99 years affected by acute myocardial ischemia found that patients with the arginine variant showed increased levels of Troponin I and CK$\mathrm{MB}$, two serum markers that correlate with the extent of ischemic damage, compared to patients with proline. Their results suggest that p53 codon 72 polymorphism contributes to a genetically determined variability in apoptotic susceptibility among elderly individuals, which plays a potentially relevant role in the context of an age-related pathological condition, such as myocardial ischemia (Bonafé et al., 2004).

Kojima et al. (2004) performed a study in 132 patients. They evaluated the polymorphism of the p53 gene for luminal narrowing after coronary stent placement. They found that the loss of luminal diameter was significantly higher in the arginine homozygous genotype than in the other groups of the study.

Chilean patients showed a higher frequency of the arginine variant in subjects with CAD when compared to controls (Caamaño et al., 2009). Kojima et al. (2000) also found a significant association between the homozygous genotype arginine and narrowing of the coronary artery. Bonafè et al. (1999) revealed that the arginine variant is associated with restenosis after angioplasty. A study by Sánchez (2010) also showed that patients with the arginine homozygous genotype have a poor prognosis after stroke and increased susceptibility to apoptosis mediated by neuronal mitochondria.

We found no association between polymorphism of p53 and hypertension. Milane et al. (2014) examined the association of hypertension with age in the diagnosis of CAD and other traditional risk factors in the Lebanese population. Their results showed that hypertension and its treatment are associated with late coronary atherosclerotic manifestations.

In the present study, there was no association between $\mathrm{p} 53$ polymorphism, $\mathrm{AD}$ and diabetes and our results were confirmed by Alkhalaf et al. (2007). In an old study from 1979, they found that patients with diabetes have two to four times greater risk of developing coronary heart disease (Kannel and McGee, 1979). A literature review by Kung and Murphy (2016) on the role of p53 in metabolism, pancreatic function, glucose homeostasis and insulin resistance showed that p53 is a key player in diabetes and in the severity of diabetic phenotypes. A study conducted on a Russian population concluded that the codon 72 polymorphism of the $p 53$ gene is associated with type 1 diabetes (Spitsina et al., 2007). A research with more than 2000 Finnish patients showed that the arginine variant was identified as one of the strongest risks for type 2 diabetes (Gaulton et al., 2008). These results were confirmed by Burgdorf et al. (2011) using clinical data from more than 55,000 European patients.

Regarding the association of dyslipidemia with p53 gene polymorphism and AD, Smith et al. (2007) analyzed São Paulo (Brazil) population and found an association between the arginine allele and low levels of HDL cholesterol, which is considered a protective effect in the development of plaques of atherosclerosis. In the present study, this analysis was also performed, but we found no association. Alkhalaf et al. (2007) did not find any association

Genetics and Molecular Research 16 (3): gmr16039721 
between dyslipidemia with p53 gene polymorphism and AD. Gloria-Bottini et al. (2012) attributed a positive effect of the proline allele on the susceptibility to CAD, but only in the presence of ACP1 a genotype characterized by high enzymatic activity.

In the present study, a genotypic frequency analysis was also performed regarding smoking habits and we found no association of $\mathrm{AD}$ with tobacco consumption and polymorphism of the p53 gene. A study by Tabara et al. (2016) concluded that a modest alcohol consumption may be associated with benefits for cardiovascular disease patients. The authors showed that alcohol consumption not only increases HDL cholesterol but also decreases LDL cholesterol levels concomitantly.

In the present study, we evaluated the association between the risk factor for alcoholism, $\mathrm{AD}$ and the polymorphism of the $\mathrm{p} 53$ gene but we found no significant association. Our population has a high rate of miscegenation and heterozygotes and, according to studies, the arginine variant is more related to plaque formation because it induces apoptosis more frequently when compared to the proline variant. According to our results, there is no association between the polymorphism of the p53 gene, atherosclerosis and its risk factors in the population studied.

\section{Conflicts of interest}

The authors declare no conflict of interests.

\section{AKNOWLEDGMENTS}

We thank Pontifical Catholic University of Goiás, Goiânia, Brazil (Replicon/Prope/ $\mathrm{MGene} / \mathrm{FAPEG} / \mathrm{CNPq}$ ) for the contribution and support to make this research possible.

\section{REFERENCES}

Alkhalaf M, Al-Bustan S, Hamoda H and Abdella N (2007). Polymorphism of p53 gene codon 72 in Kuwaiti with coronary artery disease and diabetes. Int. J. Cardiol. 115: 1-6. https://doi.org/10.1016/j.ijcard.2006.01.029

Ayres M, Ayres Júnior M, Ayres DL and Santos AA (2007). BioEstat 5.0: Aplicações Estatísticas nas Áreas das Ciências Biológicas e Médicas. MCT; IDSM; CNPq, Belém, 364.

Bonafè M, Olivieri F, Mari D, Baggio G, et al. (1999). P53 codon 72 polymorphism and longevity: additional data on centenarians from continental Italy and Sardinia. Am. J. Hum. Genet. 65: 1782-1785. https://doi.org/10.1086/302664

Bonafé M, Salvioli S, Barbi C, Trapassi C, et al. (2004). The different apoptotic potential of the p53 codon 72 alleles increases with age and modulates in vivo ischaemia-induced cell death. Cell Death Differ. 11: 962-973. https://doi. org/10.1038/sj.cdd.4401415

Burgdorf KS, Grarup N, Justesen JM, Harder MN, et al.; DIAGRAM Consortium (2011). Studies of the association of Arg72Pro of tumor suppressor protein p53 with type 2 diabetes in a combined analysis of 55,521 Europeans. PLoS One 6: e15813. https://doi.org/10.1371/journal.pone.0015813

Caamaño JL, Aavedra N, Jaramillo PC, Lanas C, et al. (2009). Polimorfismo Pro72Arg delgen TP53 se asocia a enfermedad coronária em indivíduos Chilenos. Rev. Chil. Cardiol. 28. https://doi.org/10.4067/S0718-85602009000200002

Casella FA, Araújo RG, Galvão TG, Chagas ACP, et al. (2003). Inflamação e aterosclerose: integração de novas teorias e valorização dos novos marcadores. Rev. Bras. Cardiol. Invas. 11: 14-19.

D’Agostini F, Fronza G, Campomenosi P, Izzotti A, et al. (1995). Cancer biomarkers in human atherosclerotic lesions: no evidence of p53 involvement. Cancer Epidemiol. Biomarkers 4: 111-115.

Doosti A, Zamani M, Dehkordi PG, Taheri S, et al. (2011). Association of the p53 codon 72 polymorphism with colorectal cancer in South West of Iran. Sci. Res. Essays 6: 3148-3152.

Gaulton KJ, Willer CJ, Li Y, Scott LJ, et al. (2008). Comprehensive association study of type 2 diabetes and related

Genetics and Molecular Research 16 (3): gmr16039721 
quantitative traits with 222 candidate genes. Diabetes 57: 3136-3144. https://doi.org/10.2337/db07-1731

Gloria-Bottini F, Banci M, Saccucci P, Nardi P, et al. (2012). p53 codon 72 polymorphism and coronary artery disease: evidence of association with left ventricular ejection fraction. Am. J. Med. Sci. 343: 127-130. https://doi.org/10.1097/ MAJ.0b013e318223ac71

Hansson GK (2005). Inflammation, atherosclerosis, and coronary artery disease. N. Engl. J. Med. 352: 1685-1695. https:// doi.org/10.1056/NEJMra043430

IBGE (2010). Síntese dos indicadores de saúde. Available at [http:www.ibge.gov.br].

Kannel WB and McGee DL (1979). Diabetes and cardiovascular disease. The Framingham study. JAMA 241: 2035-2038. https://doi.org/10.1001/jama.1979.03290450033020

Kojima S, Goto Y, Nonogi H, Horie H, et al. (2000). Role of a p53 polymorphism in luminal narrowing after balloon coronary angioplasty. Atherosclerosis 151: 585-586. https://doi.org/10.1016/S0021-9150(00)00452-4

Kojima S, Iwai N, Tago N, K Ono, et al. (2004). p53Arg72Pro polymorphism of tumour supressor proteinis associated with luminal narrowing after coronary stent placement. Heart 90: 1069-1070.

Kung CP and Murphy ME (2016). The role of the p53 tumor suppressor in metabolism and diabetes. J. Endocrinol. 231: R61-R75. https://doi.org/10.1530/JOE-16-0324

Lattuada D, Viganò P, Somigliana E, Abbiati A, et al. (2004). Analysis of the codon 72 polymorphism of the TP53 gene in patients with endometriosis. Mol. Hum. Reprod. 10: 651-654. https://doi.org/10.1093/molehr/gah093

Levine AJ (1997). p53, The Cellular Gate keeper for Growth and Division Cell. 88: 323-331. Accessed February 7, 1997.

Manfredi S, Masetti S, Botto N, Colombo MG, et al. (2002). P53 codon 72 polymorphism in coronary artery disease: no evidence for association with increased risk or micronucleus frequency. Environ. Mol. Mutagen. 40: 110-115. https:// doi.org/10.1002/em.10098

Mansur AP and Favarato D (2012). 2012 mortalidade por doenças cardiovasculares no brasil e na região metropolitana de São Paulo. Arq. Bras. Cardiol. 99: 755-761. https://doi.org/10.1590/S0066-782X2012005000061

Milane A, Abdallah J, Kanbar R, Khazen G, et al.; FGENTCARD Consortium (2014). Association of hypertension with coronary artery disease onset in the Lebanese population. Springerplus 3: 533. https://doi.org/10.1186/2193-1801-3-533

Mohan V, Deepa R, Haranath SP, Premalatha G, et al. (1998). Lipoprotein(a) is an independent risk factor for coronary artery disease in NIDDM patients in South India. Diabetes Care 21: 1819-1823. https://doi.org/10.2337/diacare.21.11.1819

Pietenpol JA, Tokino T, Thiagalingam S, el-Deiry WS, et al. (1994). Sequence-specific transcriptional activation isessential for growth suppression by p53. Proceedings of the National Academy of Sciences oft he United States of America. 1994/03/15 00:00. 91: 1998-2002.

Sánchez JCG (2010). El impacto del polimorfismo enelCodón 72 del GEN TP53 enelpronósticodel ictus: participación de los mecanismos de muerte celular programada. Tese departamento de Medicina. Universidade de Salamanca, Espanha. Junho, 2010.

Smith MA, Silva MD, Cendoroglo MS, Ramos LR, et al. (2007). TP53 codon 72 polymorphism as a risk factor for cardiovascular disease in a Brazilian population. Braz. J. Med. Biol. Res. 40: 1465-1472. https://doi.org/10.1590/ $\underline{\mathrm{S} 0100-879 \times 2007001100007}$

Söderström LÅ, Gertow K, Folkersen L, Sabater-Lleal M, et al. (2014). Human genetic evidence for involvement of CD137 in atherosclerosis. Mol. Med. 20: 456-465. https://doi.org/10.2119/molmed.2014.00004

Spitsina EV, Iakunina N, Chudakova DA, Nikitin AG, et al. (2007). Association of polymorphous markers Pro72Arg and C(-594)CC OF TP53 gene with diabetic polyneuropathy in patients with type 1 diabetes mellitus living in Moscow. 2007. Cardiologia 88 (Suplemento): I.

Syvänen AC (2001). Accessing genetic variation: genotyping single nucleotide polymorphisms. Nat. Rev. Genet. 2: 930 942. https://doi.org/10.1038/35103535

Tabara Y, Ueshima H, Takashima N, Hisamatsu T, et al.; SESSA Research Group; J-SHIPP Study Group (2016). Mendelian randomization analysis in three Japanese populations supports a causal role of alcohol consumption in lowering low-density lipid cholesterol levels and particle numbers. Atherosclerosis 254: 242-248. https://doi.org/10.1016/j. atherosclerosis.2016.08.021

Wang YH, Wu MM, Hong CT, Lien LM, et al. (2007). Effects of arsenic exposure and genetic polymorphisms of p53, glutathione S-transferase M1, T1, and P1 on the risk of carotid atherosclerosis in Taiwan. Atherosclerosis 192: 305312. https://doi.org/10.1016/j.atherosclerosis.2006.07.029

World Health Organization (2014). Global status report on non communicable diseases 2014 [Internet]. Available at [http://apps.who.int/iris/bitstream/10665/148114/1/ 9789241564854_eng.pdf?ua=1].

Yang Y, Du K, Liu Z and Lu X (2014). Endothelial nitric oxide synthase (eNOS) 4b/a gene polymorphisms and coronary artery disease: evidence from a meta-analysis. Int. J. Mol. Sci. 15: 7987-8003 https://doi.org/10.3390/ijms15057987.

Genetics and Molecular Research 16 (3): gmr16039721 